\title{
Article
}

\section{Extractive Industries and the Social Dimension of Sustainable Development: Reflection on the Chad-Cameroon Pipeline}

Germond-duret, Celine

Available at http://clok.uclan.ac.uk/3143/

Germond-duret, Celine (2011) Extractive Industries and the Social Dimension of Sustainable Development: Reflection on the Chad-Cameroon Pipeline.

Sustainable Development . ISSN 0968-0802

It is advisable to refer to the publisher's version if you intend to cite from the work.

For more information about UCLan's research in this area go to

http://www.uclan.ac.uk/researchgroups/ and search for <name of research Group>.

For information about Research generally at UCLan please go to http://www.uclan.ac.uk/research/

All outputs in CLoK are protected by Intellectual Property Rights law, including Copyright law. Copyright, IPR and Moral Rights for the works on this site are retained by the individual authors and/or other copyright owners. Terms and conditions for use of this material are defined in the policies page. 


\title{
Extractive Industries and the Social Dimension of Sustainable Development: Reflection on the Chad-Cameroon Pipeline
}

Celine Germond-Duret*

Centre for Sustainable Development, University of Central Lancashire, Preston, UK

\begin{abstract}
With the elaboration and diffusion of the concept of sustainable development, various projects have been defined as 'sustainable', even though they do not necessarily differ from what they would have been otherwise. Even extractive industries' activities, traditionally considered as both environmentally and socially harmful, have endorsed the sustainable development idea. We discuss the reasons why the Chad-Cameroon pipeline project, which aimed at being a 'model project, did not meet the expectations in terms of sustainable development, putting the emphasis on its social dimension. Focusing on the World Bank, which played a key role in the implementation of the project, we critically examine the adoption of preventive measures, the identification of vulnerable populations and the level of participation of local populations. We argue that economic objectives still prevail over other considerations, and we question the very nature of the project as a (sustainable) development project. Copyright (C) 2011 John Wiley \& Sons, Ltd and ERP Environment
\end{abstract}

Received 24 May 2011; revised 1 November 2011; accepted 22 November 2011

Keywords: Cameroon; Chad; indigenous peoples; oil curse; pipeline; sustainable development; World Bank

\section{Introduction}

T HE CONCEPT OF SUSTAINABLE DEVELOPMENT HAS BEEN GLOBALLY ACCEPTED AND TAKEN UP IN ALL ARENAS. COMBININC in its most basic format economic development, social well-being and environmental protection, it is sometimes considered as an ideal type, not to say a utopia, a sort of 'win-win' situation without negative externalities. Development strategies, which are based on the development concept of the time, are therefore now supposed to facilitate economic development while paying attention to its environmental and social consequences. However, the literature has highlighted the difficulty, or even the impossibility, of supporting economic development without creating social disparities and using substantial amounts of natural resources, which illustrates that development comes at a price (Gotlieb, I996; Peet and Watts, 2004; Reed, I996; York et al., 2003). In practice, the economic domain generally takes precedence over other considerations because it is more about how to minimize or offset side-effects rather than truly integrating the other dimensions into economic development. The social dimension is often the forgotten one, even though people are at the centre of development 
and sustainable development. The United Nations Declaration on the Right to Development (United Nations General Assembly, I986) states that the right to development is an 'inalienable human right' (article I) and that 'the human person is the central subject of development' (article 2). As to the Brundtland definition of sustainable development, it contains 'the concept of 'needs', in particular the essential needs of the world's poor, to which overriding priority should be given' (World Commission on Environment and Development, 1987:43). So the protection of vulnerable people should be a key objective of any development intervention, in addition to environmental protection.

Among the development institutions, the World Bank has adopted safeguard policies in areas as varied as natural habitats, involuntary resettlement and dam safety to prevent its projects from causing negative side-effects. It created in 1993 an independent Inspection Panel, following internal and external pressures, to allow local populations to voice their concerns when they believe they have been negatively affected by the Bank's failure to respect its safeguard policies. However, in practice, economy remains the prevalent dimension of development. Hopwood et al. (2005) have classified the views of different actors on sustainable development according to their consideration for socioeconomic well-being and equality on the one hand, and environmental issues on the other hand, as well as to what they see as the necessary changes in society's political and economic structures (status quo, reform, transformation). Although a simplification, their classification shows that the view shared by the most important and influential international actors (World Bank, Organisation for Economic Cooperation and Development, World Business Council for Sustainable Development, European Union) is in favour of a status quo and that their concept of sustainable development does not lie on strong environmental and social concerns. Concerning the World Bank, Young (2002) considers that the consecration of the concept of sustainable development has not led to a change in thinking: 'World Bank's economic analysts and educators have continued to treat labour, capital and natural resources largely as mere variables on a graph, or externalities to equilibrium models of idealised economic development - structurally neglecting the evolving complex reality' (3x). One's own ideology and vision of sustainable Q1] development necessarily reflects upon its practice (Soderbaum, 2009).

So, while the concept of sustainable development is widely accepted, in practice the economic dimension often takes precedence over environmental and social considerations. Extractive industries in particular have been criticised as being socially and environmentally disruptive. In this article, we are interested in the role played by international development institutions to make mining activities become (sustainable) development projects. Our case study is the Chad-Cameroon pipeline project, because the involvement of the World Bank was supposed to guarantee the social and environmental soundness of the project. Our focus is on the World Bank and on the social impacts of the project in its Cameroonian section.

\section{The Chad-Cameroon Pipeline Project: Avoiding the Oil Curse?}

The Chad-Cameroon oil pipeline project comprised the exploitation of three oil fields situated in the Doba region in Chad and in the construction of a $1070-\mathrm{km}$ pipeline linking the oil fields to a storage and unloading terminal situated in Kribi, on the Atlantic Coast of Cameroon. The pipeline crosses territories of the Bakola/Bagyeli Pygmies in its Cameroonian part. ${ }^{\mathrm{I}}$ The objectives of the pipeline project were, through 'sound environmental and social private investment', 'to increase Government expenditures in Chad on poverty alleviation activities and to promote the economic growth of Chad and Cameroon through the private sector-led development of Chad's petroleum reserves and their export through Cameroon. The project [...] would provide additional resources to alleviate poverty, specifically by financing additional expenditures in health, education, rural development and infrastructure. The project would also provide needed additional Government revenues to Cameroon (as the transit country) to finance primary expenditures and to support macroeconomic stability' (World Bank, I999:3). In addition, the Cameroon Petroleum Environment Capacity Enhancement Project (CAPECE) aimed at developing Cameroon's national capacity regarding the management and alleviation of environmental impacts, was implemented in parallel

${ }^{1}$ Bakola and Bagyeli are commonly used terms to specify the Pygmy group, while the term Pygmy itself can be considered derogatory. We use the term Bakola in the rest of the article. 
to the building of the pipeline. The objective of this additional component was to allow Cameroon to guarantee the environmental sustainability of future projects in the petroleum sector. The projects also included the implementation of an Indigenous Peoples' Development Plan to guarantee that the Bakola benefit from the project, as well as the creation of two national parks to compensate for the impacts of the building of the pipeline on forests. Both projects were approved in June 2000 .

The relationship between extractive industries and development is one of controversy. It is 'contentious and ambiguous' because of both the often adverse social, environmental and economic effects of mining activities and the potential these activities could have for development (Bebbington et al, 2008:88 J). Extractive industries projects are encouraged by the World Bank, because they allow states to export their resources and generate profit, which in turn is supposed to support economic growth. However, profits are not necessarily reallocated to the poorest populations. In many countries, the exploitation of natural resources has fuelled corruption and caused or contributed to armed conflicts, and has in any case not contributed to poverty alleviation, such as in Sierra Leone, Liberia, Angola, Nigeria, Sudan and Congo (Mulugeta, 2004; see also Ikelegbe, 2006; Renner, 2002). The case that has benefited from the largest number of studies is certainly the oil exploitation in the Niger Delta. Boele et al. (2001a, 200Ib) and Wheeler et al. (2001) give a detailed account of the involvement of Shell in Nigeria and the Ogoni territories. Ite (2007) reviews the different development strategies implemented by Shell over the years. The academic literature has been prolific on the 'resource curse', which describes a phenomenon where 'countries rich in natural resources, especially oil, tend to suffer from lower living standards, slower growth rates and higher incidence of conflict than their resource-poor counterparts' (Keenan, 2005: 395). But scholars are divided on the explicative element for the absence of economic progress despite a riche endowment in natural resources: the resources in themselves, with the dependence on mineral having adverse effects on growth and equity (Auty, 1993; Ross, 2008), or economic structures (Sachs and Warner, 200x). Others argue that the lack of appropri- Q2 ate institutions and governance structure are responsible for the phenomenon (Davis and Tilton, 2002; Humphries Q3 et al., 2007), argument supported by the World Bank (Weber-Fahr, 2002). For Luong and Weinthal (2006), strong institutions are important, along with a certain dispersion of wealth (whereas concentration of wealth impoverishes the state). Studies on the resource curse are usually centred on either macroeconomic structures, governance structure and corruption, or the multinational companies exploiting the resources, which are sometimes considered as the source of all havoc, taking advantage of the lack of internal regulation and showing no interest in improving the local population's situation. It is therefore particularly interesting to look at international development institutions, the role that they can play in that respect, and how/if they can contribute to transform an extractive industry project into a (sustainable) development one. The World Bank is highly supportive of extractive industries, but it is also aware of the risks they pose. The Extractive Industries Review (2003) commissioned by the Bank recommended to make sure that governments have the capacity to address environmental and social impacts and to promote sustainable development. Its Operations Evaluation Department assessed in 2004 the Bank's activities in extractive industries and concluded that increased investment in extractive industries is likely to lead to bad development outcomes when governance is poor, and called for a shift in World Bank's support to extractive industries sectors (Operations Evaluation Department, 2004:23-24). So the World Bank has always been aware of the risks associated with extractive industries, and it decided to get involved in the Chad-Cameroon pipeline project especially to avoid the oil curse and to make it a model project. ${ }^{2}$

Despite its relatively small financial contribution, the support from the World Bank proved a crucial element in the setting-up of the project. According to the Chairman of Esso Chad (Exxon group), Tom Walters, 'the Bank's decision to participate was an important milestone and served to validate the Consortium's environmental and social assessments and mitigation plans' (Business Wire, 2000). Approval from the World Bank was seen as a prerequisite for the managing companies to obtain commercial loans (Petroleum Economist, 1999). Spokesperson for the World Bank, Robert Calderisi, explained that the reasons for the Bank's involvement in the project were to protect the environment and to help make sure that oil money was being used correctly (Siegel and Schalch, 2000).

${ }^{2}$ The three companies involved in the pipeline project are the two American companies Exxon Mobil and Chevron Texaco and the Malaysian company Petronas. The total World Bank Group financing amounted to around $9 \%$ of the estimated project cost, and $5 \%$ of the actual cost (Independent Evaluation Group, 2009: 3). The project was managed by the Chad Oil Transportation Company (TOTCO) and the Cameroon Oil Transportation Company (COTCO), which both belong partly to their respective countries and partly to the project sponsors. See Petroleum Economist, 2004. 
Clare Short, Secretary of the British Department for International Development, affirmed as well that the involvement of the World Bank in this project will help to ensure the oil resources are used for pro-poor development and improve transparency in the management of public finances; and it means that social and environmental safeguards are much stronger than would otherwise have been the case' (Atkinson, 2000).

The programme objective category of the pipeline project was 'environmentally sustainable development', and petroleum activities were envisaged as 'an exceptional opportunity to attain a viable fiscal situation and underpin sustainable development' (World Bank, 2000: I and II 8). The involvement of the World Bank was supposed to guarantee environmental protection and better project management. Moreover, its partners maintained that a great deal of effort in the consultation process was carried out. But the civil society and non-government organizations (NGOs) expressed strong concerns regarding the potential social and environmental impacts as well as Chad and Cameroon's lack of capacity, and asked for a moratorium of 2 years. However, the Bank's Board of Executive Directors approved the pipeline project in June 2000 without internal opposition. According to Calderisi, 'there was general consensus that the project had been designed as well as it could be, given the circumstances'. For him, the Bank had done its best to listen to the concerns raised by the NGOs but it had to push the project forward because the project had already been at the planning stage for 7 years (Mutume, 2000). Esso Chad commenced construction of the oil pipeline in October 2000. The pipeline was finished I year ahead of schedule and has been described as a technical and financial success, supplying Chad and Cameroon with important revenues. Chad passed a Petroleum Revenue Management Law in 1999 providing for direct revenues from the project to be allocated to development and poverty reduction. However, the Law has been amended and suspended several times, ultimately leading the World Bank to pull out of the project in September 2008.

Actors involved in the pipeline project, including the World Bank, have certainly been over-confident in their ability to create governance quickly and escape from the oil curse (Pegg, 2006: 23). In addition, the trust placed Q4 in the preventive and compensation measures and in the ability of the project to stimulate economic growth has certainly conducted to a disregard for civil society's concerns (Auther, 20II). The project aimed at eventual sustainable development, so attention should be given to the social performance and safeguards as well, and in particular to the situation of most vulnerable people. Our analysis focuses on the social impacts of the pipeline, and on its Cameroonian section. There is a need for more studies on how people experience natural resources exploitation and its impacts, as advanced by Weszkalnys (2010). We suggest three criteria that development Q6 institutions should fulfil to ensure social benefits, or at least avoid negative impacts:

(I) Assessing impacts and obstacles and taking preventive measures where needed;

(2) Identifying vulnerable people and responding to their needs;

(3) Guaranteeing local population's participation and involvement.

\section{Foresight and preventive measures}

The World Bank appointed an International Advisory Group (IAG) to identify the potential problems that could arise from the use of public revenues, as well as participation from the civil society and social and environmental impacts (Knight, 200I). During Io years, the IAG visited Chad and Cameroon at least twice a year and submitted its reports to the Bank's President and to the Board of Executive Directors. To ensure compliance with its policies, the World Bank also set up an external Monitoring Group (ECMG), run by the Italian consulting company D'Appolonia. It carried out approximately four on-site visits per year during the construction period, then one final visit upon completion. In addition, a substantial Environmental Management Plan was prepared. In fact, the Bank's efforts on the project were unprecedented both in terms of the number of staff involved and of finance spent on it. More than 50 people from the Bank were associated with the project and another 20 from the International Finance Corporation (World Bank, 2006: I2). A mechanism such as the IAG could not be systematically put in place for every project because of the cost involved and so is of exceptional nature. In fact, the Bank had never paid so much attention to the concept and design of a project (Horta et al., 2007). So on the one hand, World Bank efforts were unprecedented, but on the other, NGOs were satisfied by neither the project nor the participatory process and were concerned by the over-confidence of the actors involved. 
Environmental Impacts Assessments have been conducted, but the absence of any evaluation of cumulative impacts is eonsidered to be-a serious flaw (Inspection Panel, 2003, $\$ 51-56$ ). It demonstrates a restrictive vision of the impacts of the pipeline, whereas future oil exploitations spurred on by the project could have been considered, as well as the attractiveness of the region. Furthermore, the eventuality of other infrastructure projects could have been taken into consideration, such as the construction of a major road between Chad and Cameroon and the construction of a hydroelectric dam on the Lom and Pangar rivers near the pipeline to provide electricity to Cameroon's western region. The project should have been considered in its wider context (Inspection Panel, 2003: \$54). ${ }^{3}$ The lack of baseline data during the evaluation and assessment phases of the project against which project impacts could be measured made any impact assessment difficult. The lack of linkage between 'baseline data collection, the assessment of project impacts and the subsequent application of mitigation and management actions' is a serious concern (\$33). A national oil spill plan has been adopted in late 2009 after years of delays, but had not been made public, engendering concerns by NGOs regarding its effective implementation.

Alongside the building of the pipeline, the World Bank implemented the CAPECE project, which aimed at developing Cameroon's capacity in terms of management and alleviation of environmental impacts. So the Bank had in mind the lack of institutional capacity. But the two-speed nature of the pipeline project has been denounced, with rapid progress in the building of the pipeline on the one hand, and slow improvements in the capacity to manage the project and its social and environmental impacts on the other (IAG, 200rb). The project is now closed, and there are no longer interactions between the World Bank and Cameroon on the social and environmental issues of the project (Independent Evaluation Group, 2009: 70). The Implementation Completion Report (the evaluation carried out by the Bank's staff who worked on the project) indicates that it is important to make 'a solid pre-assessment of existing national capacities' and that the government's monitoring capabilities need to be strengthened before the start of the project (World Bank, 2006: I6). This statement was made years before by NGOs and external observers.

\section{Identification of vulnerable people and response to their needs}

The pipeline crosses the territory of Bakola Pygmies on its Cameroonian section. Bakola constitute one of the three large Pygmy groups in Cameroon, with the Baka and the Medzan. They are hunter-gatherers who live in and depend on the forest and are particularly vulnerable to external forays in the forest, as they possess no land rights. Bakola have a unique relationship with another group, the Bantus. The latter are farmers, lead a sedentary life and possess economic power. The long relationship between the Pygmies and the Bantus is one of dependency and even obedience (Pygmies are especially dependent for getting starchy food, clothing and land). Furthermore, Bakola are often mistreated by their Bantu 'masters' who do not hesitate to talk about 'their' Pygmies. They are discriminated against and are particularly vulnerable because of their lack of education (US Department of State, 2007).

An Indigenous Peoples Development Plan (IPDP) was implemented to provide these populations with benefits and assist them in four areas: agriculture, education, health and citizenship. Identity cards have been widely distributed, but the other components of the Plan have not been so successful. As to agriculture, Pygmies do not hold any ownership rights to the lands that they cultivate and use. Yet, farming is one of the pillars of the IPDP, which signifies that Pygmies are encouraged to farm and improve their ability to farm all the while having difficulty gaining the lands they use (ECMG 2001a, 2001b, 2002, 2004a, 2004b). The objective of the agriculture project was self-sufficiency in the short term and trade of surplus in the long term. Seeds and tools were distributed, but in the subsequent years the Bantus received $20 \%$ of the total number of tools allocated to Pygmies as the result of conflicts arising during the first year of the programme. At first, the Pygmies received their tools free of charge but they either gave them away to the Bantus for a derisory sum of money or they exchanged them for alcohol and tobacco. To avoid this from happening again, they later had to pay a quarter of the price for the tools. Seeds supplied to the

${ }^{3}$ It has been announced recently that the pipeline will be rerouted to make way for the Lom-Pangar dam, which will include the building of an energy production plant with a 30 megawatt capacity. It will be shifted $25 \mathrm{~km}$ from its current route because it was not constructed to withstand flooding. (See Tendersinfo, 2009a, 2009b.) 
Pygmies could not always be sowed, some were consumed (FEDEC, 2005: 19), and fields were uncultivated and weedy (ECMG, 2004b; IAG, 2006). These poor results are certainly the result of a lack of interest in increasing their agricultural production, questioning the appropriateness of the programme (even though the activities set up by the IPDP were supposed to meet Bakola wants and needs).

The promotion of education also posed problems, as children tend to leave school before the end of the year. The proposed model is indeed not tailored to children who are usually involved in hunting activities. Compulsory traditional rituals and other cultural activities, bullying from other children, work to be carried out in the Bantu homes as well as teenage pregnancies and marriages constituted additional difficulties (FEDEC, 2005: 22). Bullying is sometimes in the form of physical violence when Pygmy children get beaten up by stronger children (ECMG, 2003: 2I). During the first year, around $80 \%$ of children who received education under the IPP did not pass their annual examinations because of absenteeism (ECMG, 2004b: 49).

Regarding health, health centres provide care for Pygmies, who are mainly infected with malaria, tuberculosis and other pulmonary diseases. The programme encourages them to consult the doctor for free. Vaccines are also administered, giving priority to children and pregnant women, and anti-malaria medication has been distributed. But spiritual beliefs and mystical practices as well as a mistrust of modern medicine are among the difficulties facing the execution of this programme. Pygmies will first go to see the wizard, and then the modern doctor if the wizard does not manage to heal them (FEDEC, 2005: 26).

In sum, the Plan did not manage to respond to Pygmies' concerns and only contributed to further encourage them to become sedentary without responding to their true needs. During a study carried out in 2003 , all the villages questioned claimed that the project had destabilized their feeding habits and livelihood, disrupted and destroyed their hunting grounds, affected their health, destroyed plants with high remedial value and other forest products and disturbed the environment (Planet Survey and CED, 2003). Half of the people also responded that the project and its consequences had exacerbated inter-community conflicts between Pygmies and Bantus, mainly for questions of compensation and land rights, and intra-community conflicts because of the changes in Pygmies' lifestyle, seen as a positive or a negative development. This is a phenomenon Boele $e$ t al. (2001a) also note in the case of Nigeria, with temporary employment encouraging young people to imitate mainstream culture, causing divisions inside the communities. The Bakola also suffered from increased vulnerability because of the contact with outsiders (IAG, 200Ia: I9). Generally speaking, the migration of workers also spawned an increase in alcoholism and public unrest (Jaboeuf, 2004).

Measures to protect the environment itself have been at the origin of social problems. In Cameroon, two national parks have been created to compensate for the impacts of the building of the pipeline on coastal forests, the Djerem and the Campo Ma'an Parks. The Campo Ma'an Park clashed against Bakola interests by prohibiting hunting and gathering activities in the park, resulting in negative repercussions on their cultural heritage and knowledge and leading to a disruption of their livelihood (Nelson and Hossack, 2003; Auther, 2012). Sixty-one per cent of hunting ground in the region is situated inside what is now the national park, leaving very little space for hunting outside the park. In addition, the areas authorized for hunting are also authorized for forestry where the noise from the machines scares the game away. Hunting constitutes the main source of protein. In addition, it is important for family ties as collective hunting strengthens social cohesion. The status of a member of the community is determined by the size and dangerousness of the game he brings home. Game also serves as a gift, dowry or goods for trading within the community and between different communities. It also plays a role in traditional medicine such as the consumption of certain species or application of ointments made from animals to treat certain wounds and illnesses (Noudjieu Cheumani, 2005: 69). In fact, the creation of the park did not take into account certain endogenous factors such as the traditional use of space by local populations (Noudjieu Cheumani, 2005: 72; IAG, Q8 2002: 8). In fact, even the Pygmies living far from the pipeline were affected by the Campo Ma'an Park, indicating that its impacts were not only felt along the pipeline route.

Besides the IPDP and the creation of the Park, the populations affected by the pipeline, Bakola or others, received compensation for the damage caused. However, the compensation system was often inadequate, as illustrated by the case of the Bakola who received monetary compensation while having very little experience of money. Many individuals money on beer, parties and extra wives. Other villages simply stopped farming, thinking that the oil companies were going to take care of them (Murphy, 2000). Compensation based on land use was not applicable in the case of the Bakola and their use of the forests because they did not plant the trees. The same applies 
to the farmed lands, which do not belong to them either. The goods received were often of bad quality or unsuitable, or took too long to be provided. Broadly speaking, the aid given to the Bakola was supposed to be development programmes but looked more like occasional assistance:

A few bags of rice, a few kilos of fish and a bit of salt distributed here and there in a sporadic manner do not really represent anything in the process of sustainable development which is a fundamental need of the Bagyeli community. On the contrary, this model of development renders them more dependent, rather than providing the bases for sustainability. It is not occasional aid that is needed, but sustainable programs (Planet Survey and CED, 2003).

In addition to the Pygmies' situation, social conditions during the building of the pipeline were severely denounced, as well as human rights violations. In September 2005, Amnesty International published a report according to which 'in Chad and in Cameroon, people's rights, be them of communities working or living in the pipeline area or of the population in general, are largely ignored' (Amnesty International, 2005). In Chad, criticism of the project was severely repressed. In 1998 , a Chadian Member of Parliament who spoke negatively about the project was sent to jail (Murphy, 2000). A local radio criticizing the project was closed and a demonstration supporting human rights and opposing the pipeline was banned (Mulugeta, 2004; Lynas, 2005). In July 2005, a Cameroonian foundation (FOCARFE), acting on behalf of populations affected by the pipeline, went to the Peoples' Tribunal of Cameroon, a 'tribunal of opinion, not of power'. Made up of important religious figures, politicians and lawyers, the court judged to charges and condemned COTCO and its subcontractors 'for failure to respect social and economic rights, in particular the pre-established standards relating to workers rights and environmental protection' (Chedjou, 2005). As to the construction itself, in addition to precarious conditions, favouritism was shown towards certain workers, with white people being better accommodated than the local population (Comité de Pilotage, 2002). Workers went on strike to denounce this 'housing apartheid' and low-wages (PANA Daily Newswire, 200I). Inflation was also observed in the region of the pipeline (Mbongo, 2002). The building sites attracted prostitutes, which promoted the spread of sexually transmitted infections. The absence of baseline studies on HIV/AIDS and of a long-term plan to minimize the risk of contamination is a serious flaw of the project. ${ }^{4}$ The World Bank was aware of the need to conduct a regional assessment of this problem (Inspection Panel, 2003: \$50).

\section{Local population's participation and involvement}

Before the beginning of the project, ExxonMobil stated that the Consortium led countless consultations, that tens of thousands of people in Chad and Cameroon had the chance to express their point of view on the project and that the level of consultation was 'unprecedented in Africa and, perhaps, the world' (Parliamentary Brief, 2003). It stated that the Consortium worked with anthropologists, scientists and engineers to lower the negative social and environmental impacts. According to a member of the European Parliament, it was a 'striking example of the way governments and the international private sector can work together with multilateral institutions to completely transform a poor country's prospects' (Parliamentary Brief, 2003). An unsatisfactory level of consultation was strongly denounced by NGOs, though, and repression was very strong in many places (US Department of State, 2004). In fact, not all the stakeholders involved share the same opinion on this point. On the one hand, NGOs state that the information was insufficient or not correctly communicated and that the affected populations, notably the Pygmies, were not consulted adequately, preventing a true participative process to take place. Over the years, the IAG and ECMG reports repeatedly stated that there were communication problems, that the information on the project was not provided in a satisfactory manner and that the participation process was inadequate. On the other hand, according to the World Bank Implementation Completion Report, the information and communication

${ }^{4}$ Due to the absence of baseline data, it is difficult to say for sure if, and to which extent, cases of HIV/AIDS have increased. The organization FEDEC, in charge of the implementation of the Indigenous Peoples Development Plan, carried out free screening among Bakola populations and noted an 'exponential growth' of sexually transmitted infections and HIV/AIDS. 
period was actually 'intense' and the participative approach 'innovative', which shows the difference of perception between the Bank and the independent mechanisms.

During a survey conducted in 2000 among Bantus and Pygmies living close to the pipeline, only $25 \%$ of respondents estimated having a good or quite good knowledge of the pipeline, including mostly Bantus. Almost $70 \%$ felt that they were not involved in the project (Planet Survey and CODEBABIK, 2000). Three years later, another survey revealed the lack of knowledge of Pygmies on the pipeline; $98 \%$ of the-Balkela were illiterate but despite this, leaflets, brochures and posters were distributed during the communication and information awareness campaign (Planet Survey et CED, 2003: 12). In fact, the Bakola would have been mainly informed to keep far away from the site during the construction (Horta et al., 2007: 19.). In addition, Pygmies' traditional decision-making method does not rest on the transfer of power to a leader but on the consultation of the entire community. Consultations carried out with just a few individuals or in certain villages may have not been representative of the whole community, as illustrated by Herrygers's study in which the Pygmieg expressed different needs and desires to those reported in the IPDP (Herrygers, 2005). Conversely, it also seems that the Pygmes themselves are divided on certain options presented by the development plan and on their future in general. Hence, alternatives would need to have been provided in line with the different aspirations present, which only a large and widespread consultation and participation process could have achieved.

\section{Conclusion}

We proposed three criteria development institutions should meet to guarantee social benefits, or at least avoid negative impacts: preventive measures, responding to the needs of vulnerable people, and guaranteeing participation and involvement of the local population.

The World Bank has adopted safeguard policies over the last decades, and in the case of the pipeline project, it adopted mechanisms to guarantee their compliance and the absence of environmental and social disruption. It devoted a lot of resources and consulted with numerous experts, including anthropologists, to guarantee the success of the project. These measures have not prevented some serious flaws appearing, and it seems that the World Bank has somehow been naive, or over-confident in its capacity, or the recipient countries' capacity, to overcome difficulties or take the right decisions. According to its mandate, the Bank is not supposed to interfere in countries' political affairs, which limits the scope of its interventions, and restricts governance to a purely technical concept. But above all, and as 'safeguard' indicates, it is more about the prevention of side-effects than a sustainable development process. Even though the World Bank allocates many resources to research on social development and environmental protection (for example, the 2010 World Development Report was devoted to Climate Change), development is still mainly conceived as economic growth. As to private companies involved in extractive industries projects, many endorsed Corporate Social Responsibility principles, but they remain private companies aiming at maximization of profit, and cannot substitute for development institutions. Ite's study of Shell's development strategies in Nigeria (Ite, 2007) and Ihlen's analysis on the rhetoric used by oil industries (Ihlen, 2009) are highly instructive in that respect.

As to vulnerable people, if we identify the social dimension of sustainable development mainly as equity, it makes reference to the non-exclusion of particular groups. Dempsey et al. (20Ir: 293) define the sustainability of communities as 'the ability of society itself, or its manifestation as local community, to sustain and reproduce itself at an acceptable level of functioning'. In the case of the Bakola communities, while the obtaining of identity cards is a step towards their empowerment and inclusion into the wider society, we can question their ability to sustain and culturally reproduce themselves if external interventions aim at, or de facto lead to, the adoption of a sedentary lifestyle and alien way of life. No one can obviously talk on their behalf and the idea here is not to support a 'static' lifestyle and condemn any changes, whereas communities are constantly evolving and adapting. But bearing in mind the reproduction imperative, it is crucial to ensure any intervention would respond to their needs and would not make them further victims of a logic of normalization aimed at aligning all societies to the same development and cultural model. The lack of consensus within communities themselves constitutes a non-negligible obstacle.

It is obviously necessary to look beyond the sole situation of the Cameroonian Bakola to assess the social impacts of the pipeline, and in particular if the rest of the population will benefit from development and anti-poverty 
programmes in the long run. The involvement of the World Bank has contributed to social safeguards, compensation measures and short-term assistance. But short-term assistance should not be confused with development and profound structural changes through the spending of oil revenues, something that the Bank cannot guarantee.

We mentioned the participation of local populations and their involvement in the decisions as a means to avoid negative social impacts. It is necessary to make three comments. First, a satisfactory participation process lies on different criteria, depending on the stakeholders. It can go from the organization of meetings (participation here rather means diffusion of information) to the integration of local population's concerns into decisions (ultimately meaning giving a power of veto). Second, a participation process is likely to reinforce decisions already taken (Craig and Potter, I997). For Mawdsley and Rigg (2003), participation would in fact aim at achieving the dominant neoliberal agenda. The term 'tyranny' has even been used to characterize participation (Cooke and Kothari, 2004). Participatory development would give a good image of development, while in fact only strengthening the power dynamic in favour of the North. Third, the question of the representation is of crucial importance. As we have discussed, communities can be divided over key issues, and consensus may not be reached. The power structure within participants also needs to be taken into account, so as the participation process does not become a source of disturbances in itself. Fourth, in the case of World Bank projects, the host country is supposed to support the smooth organization of participation processes, but it may not be used, or willing, to give voice to the local population. This argument cannot be advanced to excuse a faulty process, because the World Bank knows beforehand where it decides to intervene.

A lot of literature has been devoted to the concept of sustainable development from a critical perspective, defining it as a buzz word, a weak concept or even an oxymoron (see for example issue 13 of this journal). For Luke, 'the sustainable development project is neither "sustainable" nor "developmental". A major difficulty defining sustainable development comes from the fact that development in itself does not mean anything, because it can mean everything. It can be a process or an objective, it can characterize an economy or a society, whereas human beings are supposed to be at the centre of the concept (see Rist, 2008 on the definition of development). In any case, the social dimension is paradoxically the forgotten one.

Even though the World Bank played a crucial role, the understanding of the project and of the disappointment it engendered needs to be tackled in its broader context and can be summarized in one key question. Was the Chad-Cameroon pipeline a development project (not to say a sustainable development project)? According to the Esso Chad President, the project should not have been called a development project (Horta et al., 2007). And it would probably not have been the case without the involvement of the World Bank. Such a labelling is misleading; it can both hide the true nature of a project and engender unrealistic expectations.

With the implementation of the aid regimen in the I950s, infrastructure, industrialization or modernization projects became 'development' projects. With the elaboration and diffusion of the sustainable development idea, projects have then often been labelled as sustainable, even though they do not necessarily differ from what they would have been otherwise. Even mining activities, traditionally considered as both environmentally and socially harmful, have endorsed the sustainable development idea, beause we now talk of 'sustainable mining' (Whitmore, 2006). In fact, everything can be sustainable now: buildings, transport, tourism, communities, cooking, fashion, etc. The diversity of activities or phenomena that can be labelled as sustainable reflects the complexity of the concept, which can mean so many different things to different actors. In practice, the core idea of development has broadly remained the same, and prefixes (human, participatory, sustainable, etc.) have been added to integrate new trendy ideas, without engendering a profound paradigm shift.

It can even lead to contradictions, as shown by Rist in the case of the Millennium Development Goals: 'The division of "development" into a set of discrete goals actually paralyses thought and stands in the way of their systemic linkage: for instance, although the numbers of the poor have declined, especially in Asia, this has been at the price of increased pollution and growing inequalities. These trends are noted, to be sure, but there is no attempt to explain how the different phenomena are related. Why this blindness to the fact that efforts to achieve one goal make it impossible to achieve another, equally important one? [...] Perhaps the reason is that otherwise it would be necessary to question the whole "faith" in development' (Rist, 2008: 235). Development remains a contested concept, and while it is now globally associated with environmental and social considerations, it suffers from two weaknesses: the very links between its different components need to be further clarified, while the practice remains for the most focused on economic objectives. When extractive industries projects are labelled 
as development or sustainable development projects, it gives the feeling that they will benefit the whole society and be beneficial, or at least not harmful, to the environment, while in reality the environmental and social elements may only play a minor role and constitute a secondary objective, if any. The 'development' or 'sustainability' label should not be used to justify a project that will barely pay attention to its non-economic dimensions and that will, at its best, increase economic growth without alleviating poverty. It would certainly avoid unrealistic expectations and unnecessary disappointments.

\section{References}

International-A. 2005. Contracting out of human rights: the Chad-Cameroon pipeline. Amnesty International Publications. September 2005. Atkinson M 2000. Short snubs Greenpeace to back African oil project. Manchester Guardian weekly 2000.

Auty RM. 1993. Sustaining Development in Mineral Economies: The Resource Curse Thesis. Routledge: London.

Bebbington A, Hinojosa L, Humphreys Bebbington D, Burneo ML, Warnaars X. 2008. Contention and Ambiguity: Mining and the Possibilities of Development. Development and Change 39(6): 887-9I4.

Boele R, Fabig H, Wheeler D. 20ora. Shell, Nigeria and the Ogoni. A Study in Unsustainable Development: I. The Story of Shell, Nigeria and the Ogoni People - Environment, Economy, Relationships: Conflict and Prospects for Resolution. Sustainable Development 9: 74-86.

Boele R, Fabig H, Wheeler D. 2oorb. Shell, Nigeria and the Ogoni. A Study in Unsustainable Development: II. Corporate Social Responsibility and 'Stakeholder Management' versus a Right-based Approach to Sustainable Development. Sustainable Development 9: I2I-I35.

Bank Information Genter. 2008. President of Chad nullifies-World Bank agreement to grab-oil money and crack down on opponents. 6 March 2008. http://www.bicusa.org/en/Article-3693-aspx [G January-zorr]

Business Wire. 2000. Exxon Mobil affiliate commences major African development project. 18 October 2000.

Business Wire. 2008. Oil Expert Preject Continues to Deliver Revenue and-Greate Jobs in Chad. ro-Oetober-2008.

Chedjou A. 2005. Pipeline Tchad-Cameroun: "'Tribunal des peuples" accuse! Journal Bubinga 2005.

Comité de pilotage du suivi indépendant du projet de pipeline Tchad-Cameroun et Catholic Relief Services - Cameroon. 2002. Rapport de monitoring indépendant du projet Tchad-Cameroun, Janvier - Juin 2002. FOCARFE, CED, ERA-Cameroun, Service CEcuménique pour la Paix. Septembre 2002

Gollier P. 2000. The Economic Causes of Civil Conflict and Their Implications for Policy. Is June zo00.

Cooke B, Kothari U. 2004 (eds). Participation: the new tyranny? Zed Books: London. 200I, 3 rd impression.

Craig D, Potter D. 1997. Framing participation: development projects, professionals and organisations. Development in Practice 7(3): $230-236$.

Davis GA, Tilton JE. 2002. Should Developing Countries Renounce Mining? A Perspective on the Debate. Report prepared for the International Council on Mining and Metals. ICMM: London.

Defense and foreign affairs daily. ICI ruling against Nigeria and Balkassi- a further blow for Obassanjo. II Oetober 2002:

Dempsey N, Bramley G, Power S, Brown C. 2orr. The Social Dimension of Sustainable Development: Defining Urban Social Sustainability. Sustainable Development $19(5): 289-300$.

Escobar A. I995. Encountering Development: The Making and Unmaking of the Third World. Princeton University Press: Princeton.

Esteva G. I992. Development. In: Sachs W (ed). The development dictionary: a guide to knowledge as power. Witwatersrand University Press: Johannesburg; $\mathrm{I}-25$.

External Compliance Monitoring Group. 20ora. Initial visit of the D'Appolonia ECMG Team to Chad and Cameroon, D'Appolonia. 28 March 2001 .

External Compliance Monitoring Group. 200Ib. Second Site Visit, May-June 200I, Chad Export Project, CAPECE, D'Appolonia. 28 June $200 \mathrm{r}$. External Compliance Monitoring Group. 2002. Sixth Site Visit, September-October 2002, Chad Export Project, CAPECE, D'Appolonia. November 2002 .

External Compliance Monitoring Group. 2003. Eighth site visit, Chad Export Project, CAPECE, May 2003. June 2003.

External Compliance Monitoring Group. 2004a. Tenth Site Visit, April-May 2004, Chad Export Project, CAPECE, D'Appolonia. June 2004.

External Compliance Monitoring Group. 2004b. First Site Visit - Post-Project completion, December 2004, Chad Export Project, CAPECE, D'Appolonia. January 2005 .

External Compliance-Monitoring Group. 2005. Chad Export Project, Cameroon Petroleum Gapacity Enhancement-Project, Chad Petroleum Sector-Management-Gapacity-Building Project, Second Site-Visit-Post-Project Completion November 2005. December 2005.

Extractive Industries Review. 2003. Striking a better balance: The final report of the Extractive Industry review. Vol.r: The World Bank Group and Extractive Industries. December 2003.

FEDEC, Fondation pour l'Environnement et le Développement. 2005. Plan pour les peuples autochtones vulnérables: Rapport de fin de la phase I. May 2002 - April 2005.

Gotlieb J 1996. Development, environment and global dysfunction. CRC Press: Boca Raton.

Herrygers CM 2005. Structural violence, health and the Chad-Cameroon oil pipeline. Master Thesis, Washington State University, Department of Anthropology. May 2005.

Hopwood B, Mellor M, O’Brien G. 2005. Sustainable Development: Mapping Different Approaches. Sustainable Development Ir: $32-52$.

Horta K, Nguiffo S, Djiraibe D. 2007 . The Chad-Cameroon oil \& pipeline project: a project non-completion report. Environmental Defense, Center for Environment and Development, Chadian Association for the promotion and defence of human rights. April 2007. 
Humphreys M, Sachs J, Stiglitz J. 2007 (eds). Escaping the Resource Curse. Initiative for Policy Dialogue. Columbia University Press: New York. Ihlen $\varnothing$ 2009. The Oxymoron of 'Sustainable Oil Production': the Case of the Norwegian Oil Industry. Business Strategy and the Environment I8: $53-63$.

Ikelegbe A 2006. The Economy of Conflict in the Oil Rich Niger Delta of Nigeria. African and Asian Studies 5(I): $23-56$.

Independent Evaluation Group. 2009. The World Bank group program of support for the Chad Cameroon petroleum development and pipeline construction: Program Performance Assessment Report. Report 50315. I6 September 2009.

Inspection Panel. 2003. Investigation Report, Cameroon Petroleum Development and Pipeline Project (Loan No. 7020-CM) and Petroleum Environment Capacity Enhancement (CAPECE) Project (Credit No. 3372-CM), Report 25734. 2 May 2003

International Advisory Group. 2001a. Report of mission to Cameroon and Chad, July I9-August 3, 2001. 28 September 2001.

International Advisory Group. 200Ib. Report of mission to Cameroon and Chad, I4-25 November 200I. 2I December 200 I.

International Advisory Group. 2002. Report of mission to Cameroon 7-18 April 2002. 24 May 2002.

International Advisory Group. 2006. Report of Mission Ir to Cameroon 15-23 March 2006. 26 April 2006.

Ite UE. 2007. Changing Times and Strategies: Shell's Contribution to Sustainable Community Development in the Niger Delta, Nigeria. Sustainable Development 15: I-I4.

Jaboeuf V. 2004. L'oléoduc Tchad Cameroun ou le cynisme de la Banque Mondiale. The Dominion. I3 December 2004.

Keenan JH. 2005. Chad-Cameroon Oil Pipeline: World Bank \& ExxonMobil in 'Last Chance Saloon'. Review of African Political Economy 32 (ro4/ro5): $395-405$.

Knight D. 200I. Environment: watchdog appointed for Chad-Cameroon pipeline. IPS-Inter Press Service. I March $200 \mathrm{r}$.

Luong PJ, Weinthal E. 2006. Rethinking the Resource Curse: Ownership Structure, Institutional Capacity, and Domestic Constraints. Annual Review of Political Science 9: 24I-263.

Lynas M. 2005. A helping hand for big oil: observations on overseas aid. II April 2005.

Mawdsley E, Rigg J. 2003.The World Development Report II: continuity and change in development orthodoxies. Progress in Development Studies 3 (4): $271-286$.

Mulugeta S. 2004. Crude in Africa. Newsday. 9 April 2004.

Murphy J. 2000. Where oil flows, future holds promise, threat Chad: a pipeline to the Cameroon coast will change the lives of the hunters, farmers, fishermen who dwell nearby - for good or ill, they do not know. The Baltimore Sun. 3 September 2000.

Ausa T. r997. Indigenous - Cameroon: pygmies face challenge of integration. IPS-Inter Press Service. 3 August r997.

Mutume G. 2000. Development: World Bank blasted for Chad/Cameroon pipeline. Interpress service. 6 June 2000.

Nelson J, Hossack L. (eds). 2003 . From principles to practice: indigenous peoples and protected areas in Africa. Forest Peoples Programme: Moretonin-Marsh.

Noudjieu Cheumani C. 2005. Approches de gestion durable de la chasse dans l'unité technique opérationnelle de Campo Ma'an (UTOCM) Sud Cameroun. Master Thesis, Université de Liège, Faculté Universitaire des Sciences Agronomiques, Gembloux.

Operations Evaluation Department. 2004. Evaluation of the World Bank Group's Activities in Extractive Industries: Factoring in Governance. Background Paper. Washington, D.C., I September 2004; 23-24.

PANA Daily Newswire. 200I. Strike Disrupts Work on Chad-Cameroon Pipeline. 29 December $200 \mathrm{I}$.

Parliamentary Brief. CSR Case Study ExxonMobil. ExxonMobil, helping transform the economic and social prospects of Chad, the fifth poorest country in the world. I May 2003 .

Peet R, Watts M. (eds). 2004. Liberation Ecologies: Environment, Development, Social Movements. 2nd edition. Routledge: London.

Petroleum Economist. 1998. Chad: meeting environmental and social-challenges-head-on. 25 November r998.

Petroleum Economist. 1999. Oil export pipeline projects on track. 26 August 1999.

Petroleum Economist. 2004. Pipeline: Chad-Cameroon: against all odds. 26 February 2004.

Planet Survey and Centre For Environment And Development. 2003. Report on the Bagyeli communities living along the pipeline route Southern Cameroon. February-March 2003. Presented at the International Workshop on Indigenous Peoples, the Extractive Industries and the World Bank, April 2003.

Planet Survey and CODEBABIK. 200o. Rapport de l'enquête sur le degré d'implication des peuples autochtones dans le cycle du projet Pipeline Tchad-Cameroun. 9-10 May 2000.

Reed D I996. Structural adjustment, the environment, and sustainable development. Earthscan: London.

Renner M. 2002. The Anatomy of Resource War. Worldwatch Paper I62. Worldwatch Institute: Washington, D.C.

Rist G 2008. The History of Development: From Western Origins to Global Faith. Zed Books: New York.

Ress ML. 1999 . The Politieal Economy of the Resource Curse. World Politites-5x(2):297 322 .

Ross M 2008, Mineral Wealth, Conflict, and Equitable Development. In Bebbington A, Dani A, de Haan A, Walton M (eds). Institutional Pathways to Equity: Addressing Inequality Traps. The World Bank: Washington DC; I93-216.

Sachs J, Warner A. 1995. Natural Resource Abundance and Economic Growth. NBER Working Paper Series 5398. National Bureau of Economic Q28 Research: Cambridge, MA.

Siegel R, Schalch K, 2000. World Bank expected to approve controversial oil pipeline project in Chad. National Public Radio. 5 June 2000. Soderbaum P 2009. Making Actors, Paradigms and Ideologies Visible in Governance for Sustainability. Sustainable Development I7: 70-8I.

Tendersinfo. 2009a. Cameroon: A section of Chad-Cameroon pipeline to be moved over $25 \mathrm{kms}$ away. 23 September 2009.

Tendersinfo. 2009b. Chad: Chad-Cameroon pipeline re-routed. I October 2009.

United Nations General Assembly. Declaration on the Right to Development, A/RES/4I/128, 4 December 1986.

US Department of State. 2004. Country Report on Human Rights practices: Cameroon, 2003. Released by the Bureau of Democracy, Human Rights, and Labor. 25 February 2004. 
US Department of State. 2007. Country Report on Human rights practices: Cameroon. Released by the Bureau of Democracy, Human Rights and Labor, ir March 2008.

Washington Post. 2000 . Tough Choice in Africa. Editorial. 8 December 2000.

Weber-Fahr M 2002. Treasure or Trouble? Mining in Developing Countries. The World Bank and International Finance Corporation: Washington DC.

Wheeler D, Rechtman R, Fabig H, Boele R. 200r. Shell, Nigeria and the Ogoni. A Study in Unsustainable Development: III. Analysis and Implications of Royal Dutch/Shell Group Strategy. Sustainable Development 9: 177-I96.

Whitmore A 2006. The emperor's new clothes: Sustainable mining? Journal of Cleaner Production 14: 309-3I4.

World Bank. I999. Cameroon-Chad Petroleum and Pipeline Project, Project Information Document. Report No. PID7288. 23 June I999. World Bank, Washington DC.

World Bank. 2000. Project Appraisal Document on proposed International Bank for Reconstruction and Development Loans in amounts of US\$ 39.5 million to the republic of Chad and Us $\$ 53.4$ million to the republic of Cameroon and on proposed International Finance Corporation Loans in amounts of tw\$ $\$ 100$ million in a-loans and up to $\$ 300$ million in b-loans to the Chad Oil Transportation Company, S.A. and Cameroon Oil Transportation Company, S.A. for a Petroleum development and pipeline project. Report No. I9343 AFR. I3 April 2000. World Bank, Washington DC.

World Bank. 2006. Implementation Completion Report on the two IBRD loans in the amount of US\$39.5 million and in the amount of US\$53.4 million respectively to the Republic of Chad and the Republic of Cameroun for a petroleum development and pipeline project. Report $\mathrm{n}^{\circ}$ 36560-TD. I5 December 2006. World Bank, Washington DC.

World Bank. 2008. World Bank statement on Chad-Cameroon pipeline. Press Release-2009/073/AFR. 9 September-2008. World-Bant, Q31, Washington $D E$.

World Commission on Environment and Development. 1987. Our Common Future. Oxford University Press: Oxford.

York R, Rose EA, Dietz T. 2003. Footprints on the earth: the environmental consequences of Modernity. American Sociological Review 68(2): 279-300.

Young $\mathrm{Z}$ 2002. A new green order? The World Bank and the Politics of the Global Environment Facility. Pluto Press: London. 